\title{
MENELAAH POLA KOMUNIKASI DALAM DIALEKTIKA AL- QUR'AN DAN IMPLEMENTASINYA DALAM BERDAKWAH MULTIKULTURAL
}

\begin{abstract}
Anwar*
ABSTRAK

Artikel ini membahas tentang pola komunikasi dalam dialektika alQur'an dengan realitas Arab. Al-Qur'an adalab kitab suci yang tidak hanya dijadikan sebagai sumber bukum, namun proses dialektikanya pun dapat dijadikan acuan melakukan dalam berkomunikasi. Ada tiga pola dialektika yang dapat dijadikan acuan dalam komunikasi, yaitu: tahrim (pelarangan), taghyir (merubah), dan tabmil (melanjutkan). Tabrim dilakukan pada realitas budaya yang bertentangan dengan nilai-nilai islami, namun tidak dilakukan secara totalitas. Taghyir (perubahan) dilakukan merubah bagain tertentu dari budaya namun tidak menghilangkan eksistensi budaya yang sedang berlaku. Tahmil (melanjutkan), yakni melanjutkan sistem budaya yang sudah ada tanpa perlu merubah, apalagi melarang.
\end{abstract}

\section{Kata Kunci: Pola Komunikasi, Dialektika Alquran, Dakwah Multikultural}

\section{PENDAHULUAN}

Berbagai persoalan yang dihadapi umat Islam dewasa ini, terutama bagaimana orang lain mempersepsi Islam. Berbagai bentuk stereotip diberikan mulai dari teroris, radikal, dan banyak pelabelan-pelabelan lainnya. Begitu juga di media internet, berbagai bentuk pelecehan dan penistaan ditujukan kepada agama dan umat Islam. Fenomena ini menunjukkan bahwa agama Islam berada dalam kecurigaan orang lain. Persoalannya, apakah pantas Islam dicurigai sebagai agama yang menebarkan rahmatan lil alamin bagi segenap makhluk hidup.

Terkait dengan persoalan tersebut, berbagai respon diberikan, ada sebagian menganggap umat Islam sudah jauh dari kebenaran agamanya, ada juga yang mengatakan komunikasi umat Islam cenderung memaksa diri, cenderung anarkis, bahkan tidak segan-segannya mengambil tindakan

\footnotetext{
* Penulis adalah Alumni Pascasarjana Universitas Negeri Medan, Email: anwar@iainlangsa.ac.id
} 
anarkis. Untuk mengantisipasi problematika tersebut, perlu adanya upaya penyelamatan moral dan spiritual agar menghasilkan suatu kondisi dinamis sesuai dengan tuntutan agama. Salah satu upaya yang dapat dilakukan adalah membangun komunikasi yang baik, terutama dalam berdakwah.

Dalam pelaksanaan dewasa ini, dakwah terkadang cenderung kurang mengayomi kondisi umat yang berbeda paham. Dai selalu menampilkan dirinya sebagai pemegang kekuasaan mutlak terhadap agama. Dengan dalih agama, mereka tidak segan-segannya memprovokasi suatu komunitas beragama untuk melawan komunitas lainnya. Di samping itu, pesan dakwah yang disampaikan cenderung bernada ancaman ketimbang pengayoman. Padahal seorang da'i adalah agent perubahan. Dengan demikian ia harus sangat memahami kebutuhan sasarannya. Selama ini, hal seperti itu sering dilupakan atau mungkin sengaja ditinggalkan sehingga pesan yang disampaikan kurang tepat sasaran. Beranjak dari problematika tersebut, penulis melihat perlu menggunakan komunikasi yang baik, terutama ketika dakwah pada masyarakat multikultural.

\section{DAKWAH KULTURAL SEBUAH ALTERNATIVE PENDEKATAN}

Istilah dakwah kultural merupakan gabungan dua kata, yakni dakwah dan kultural. Dakwah secara etimologi berarti "tuntutan atau seruan". Kata tersebut merupakan istilah bahasa Arab, yaitu da'a, yad'u, dan da'watan. Dalam buku Paradigma Dakwah Sayyid Qutub, Ilyas Ismail menyebutkan, kata "dakwah" merupakan bentuk mașdar dari kata kerja "da'a" (Madí), yad'u (mudâari), berarti seruan, ajakan, atau panggilan ( Ismail, 2006: 144). Istilah "seruan dan ajakan" yang digunakan dalam memaknakan arti dakwah merupakan gambaran aktivitas yang dilakukan. Dalam Al-Qur'an, dakwah diartikan dengan "seruan" (QS. 10:25), adakalanya juga diartikan dengan "doa" (QS. 2:186). Pemaknaan dakwah dengan "seruan" dan "doa" bukanlah suatu perbedaan dalam pemaknaan dakwah itu sendiri. Perbedaannya hanya tergantung pada objek (mukhâtab) yang dijadikan tujuan dakwah. Menggunakan makna " $d a$ ' $a$ " dengan "seruan" karena tujuan penyampaiannya adalah manusia. Seperti yang terlihat pada surat Yunus: 25. Sedangkan makna "dakwah" dengan "doa" karena tujuan penyampaiannya adalah Allah Swt, sebagaimana disebutkan dalam Al-baqarah: 186). Hal ini sebagaimana digambarkan dalam kajian ilmu Balaghah yang membedakan stressing suatu kata berdasar objek penyampaiannya. Dalam ilmu sering diilustrasikan dalam bentuk kata "seruan (jika dari Tuhan kepada manusia), doa (jika dari manusia kepada 
Tuhan), dan iltimas (jika orang yang menyampaikan dan objeknya dalam derajat yang sama). (al-Qazwini, t.th:108).

Di samping itu, dalam al-Qur'an juga menggunakan istilah lain yang dapat disamakan stressing dengan istilah dakwah, diantaranya: Tabligh, artinya menyampaikan. Maksudnya adalah menyampaikan ajaran Tuhan kepada manusia (QS. 33:39). Amar ma'ruf, artinya menyuruh berbuat yang ma'ruf atau berbuat sesuatu yang baik (QS.22:41). Man'izah, artinya pengajaran (QS.16:125). Tabsyir, artinya penyampaian berita (gembira) (QS.39:17). Indzar, artinya pemberian peringatan (QS. 9: 122). Tazkirah, artinya peringatan (QS.87:9). Nasehat (QS. 7:79). Istilah-istilah tersebut dalam penggunaannya mempunyai kesamaan makna. Oleh sebab itu, sangatlah memungkinkan ketika kata-kata tersebut dalam realitas digunakan sebagai kata ganti untuk dakwah. Seperti, ceramah diistilahkan dengan mau'izah dan banyak pengistilahan lain digunakan masyarakat untuk menggantikan istilah dakwah, namun tetap dalam kegiatan yang sama dengan dakwah.

Beranjak dari pengertian etimologi tersebut, secara terminologi dakwah dipahami sebagai mengajak atau menyeru manusia melakukan perbuatan dari suatu yang tidak dikehendaki sesuai dengan norma yang dikehendaki pada nilai-nilai agama. (Ali, 2007:177 Selain itu, Abdullah Ali mendefinisikan dakwah seruan menuju jalan Allah dengan kebaikan dan kebenaran sesuai ajaran al-Qur'an. (Ali, 2007:176). Definisi yang sama juga dikemukakan Anton Timur Jailani dalam Forum Majalah Dakwah, dakwah merupakan menyeru kepada manusia untuk berbuat baik, dan menjauhi yang buruk sebagai pangkal kekuatan, mengubah masyarakat dari keadaan yang kurang baik kepada keadaan yang lebih baik, sehingga merupakan suatu pembinaan. (Pusat Dakwah Indonesia, 1972: 127).

Dari definisi di atas dalam proses dakwah terdapat tiga unsur yang saling mempengaruhi, yakni; da'i, maddah, dan mad'un. Da'i dipahami sebagai agen atau actor yang berusaha memberikan pengaruh terhadap sasarannya. Maddah merupakan pesan yang disampaikan. Merujuk pada definisi di atas, pesan adalah amar ma'ruf nahyi al-munkar atau diistilahkan kebaikan dan keburukan. Sedangkan mad'un merupakan sasaran atau objek dari pesan yang disampaikan. Ketiga unsur tersebut dalam proses dakwah mempunyai bagian masing-masing namun tetap saling mempengaruhi. Da'i dan mad'un merupakan dua unsur yang berada dalam kondisi social dan kepribadian yang berbeda. Däi merupakan individu atau kelompok yang mempengaruhi, tentu dalam hal ini melakukan berbagai upaya agar sasaran yang dapat dengan mudah menerima, bahkan mengikuti ajakan da'i.

Adapun kultural secara etimologi berasal dari kata budhayah, 
merupakan bentuk jamak dari kata buddhi yang berarti budi atau akal. Dengan demikian, ketika penyebutan istilah kebudayaan sering dikaitkan dengan hal-hal yang berkaitan dengan budi dan akal. (Koentjaningrat, 1976:19) Peran akal atau dalam kebudayaan adalah hubungan pembentukan. Dalam hal ini, individu atau kelompok melalui kreasinya dapat menciptakan sebuah budaya tertentu, ketika kreasi tersebut diciptakan secara berulang-ulang. (Zuhriy, 2011: 290)

Dengan demikian, budaya tidak lahir dengan sendirinya, melainkan ada proses penciptaan yang dilakukan berulang-ulang. Di samping itu, budaya juga dapat membentuk dan mempengaruhi individu atau kelompok lainnya. Dengan kata lain, suatu komunitas masyarakat membentuk budaya melalui aktivitasnya yang dilakukan berulang-ulang, kemudian budaya tersebut dapat membentuk generasi setelahnya. Namun, mungkin saja budaya yang sudah terbentuk dalam suatu komunitas dirubah dalam bentuk yang lainnya, yakni, ketika budaya tersebut dianggap tidak relevan atau kurang memberikan solusi dalam kehidupan masyarakat. Misal, kehidupan masyarakat Jahiliyah yang sangat bergantung terhadap keajaiban berhala dirubah kearah ketergantungan terhadap Tuhan.

Memang melakukan perubahan terhadap suatu budaya yang sudah mengakar bukanlah perkara mudah. Keuntungan dan popularitas menjadi kenyamanan tersendiri bagi komunitas masyarakat. Bagi masyarakat, kebiasaan yang dilakukan setiap saat adalah kebenaran yang harus dipertahankan. Mengganti atau merubah merupakan suatu kesalahan, bahkan cenderung menjadi persinggungan yang mengarah ke konflik. Namun demikian bukan berarti tidak ada peluang untuk melakukan perubahan, asalkan dilakukan dengan lebih sistematis dan manusiawi perubahan dapat dilakukan, meskipun sudah mengakar dan menjadi ideology dalam kehidupan.

Terlepas dari persoalan tersebut, merujuk pada pengertian dakwah sebagai aktivitas menyeru untuk melakukan perubahan ke arah yang lebih baik dan pengertian kultural kebiasaan yang dilakukan masyarakat dalam kehidupannya, maka pengertian dakwah kultural adalah aktivitas dakwah yang menekankan Pendekatan Islam kulural. (Sulthon, 2003:26) Dengan kata lain, dakwah kultural merupakan sebagai upaya untuk memahami dan menggunakan potensi-potensi kultural masyarakat Islam sebagai wahana untuk menanamkan Islam yang membumi, yakni Islam yang bisa merubah potensi menjadi gerak kemajuan sosial.(Suparto, 2009:155)

Dari definisi tersebut, dakwah kultural lebih luas dibandingkan dengan sistem dakwah konvensional yang hanya bertumpu pada satu sasaran agama (ibadah). Dakwah kultural tidak hanya pada persoalan tersebut, namun menjadikan semua aspek kehidupan sebagai bagian untuk 
melakukan perubahan. Dengan kata lain, merubah tingkat kesadaran beragama masyarakat dan memperhatikan dimensi-dimensi ekonomi, pendidikan, dan lain sebagainya. Hal ini didasari oleh asumsi bahwa persoalan keberagamaan masyarakat tidak hanya dipengaruhi keyakinan dan pemahaman keagamaan, melainkan factor kebutuhan dan kehidupan social.

Persoalannya, mungkinkah melakukan dakwah dengan pendekatan kultural terhadap mad'un yang berbeda social budaya dengan da'i? Hal ini sangatlah mungkin dilakukan, sebab social dan budaya yang hidup dalam masyarakat sangat terikat oleh kenyataan dibentuk oleh struktur dan diposisikan oleh relasi-relasi dari suatu struktur yang ada. Namun harus diakui bahwa struktur-struktur tersebut dibentuk oleh manusia sehingga bukan sesuatu yang mustahil manusia dapat merubah, bahkan menciptakan kondisi-kondisi social dan budaya baru. (Subaidi, 2014:173)

Dalam hal ini, dakwah kultural hadir untuk mengukuhkan kearifan-kearifan lokal yang ada pada suatu pola budaya tertentu dengan cara memisahkannya dari unsur-unsur yang bertentangan dengan nilai-nilai islami. Dalam hal ini, da'i tidak serta merta menolak suatu kebudayaan yang berlaku dalam komunitas masyarakat, tetapi lebih mengedepankan persuasive dialektis agar mad'un tidak merasa bahwa ia sedang ditantang.

Fenomena dakwah KH. Muhammad Khoiron Suaeb pada komunitas PSK dalam penelitian A. Sunarto AS di lokalisasi Kota Surabaya menjadi gambaran menerapkan dakwah kultural dalam suatu komunitas. Aktivitas dakwah yang dilakukan KH. Muhammad Khoiron Suaeb tidaklah mudah, Ia harus merubah tatanan kehidupan PSK yang jelas bertentangan dengan syar'i namun dianggap lazim oleh mereka. Menghadapi komunitas seperti ini, ia tidak serta merta menyalahkan, namun memberi pemahaman "Tuhan membuka pintu maaf terhadap hambanya, selama ia tidak melakukan syirik". Ungkapan tersebut dijadikan pesan utama setiap berjumpa dengan PSK dan Mucikari. Keunikan dakwah KH Muhammad Khoiron Suaeb, setiap kali melaksanakan aktivitas dakwah ada saja PSK yang mohon diri untuk melayani lelaki hidung belang. Fenomena tersebut terjadi, namun KH Muhammad Khairon sangat sabar menghadapi tanpa adanya upaya pencegahan secara totalitas. (Sunarto, 2013: 330-350)

Selain fenomena tersebut, praktek dakwah dengan pendekatan kultural juga dilakukan oleh walisongo ketika menyebarkan Islam di pulau Jawa. Sebagaimana dikemukan oleh Afif Rifa'i, Walisongo ketika berdakwah di Jawa tidak menggunaka kekuatan politik, tetapi dengan pendekatan kebudayaan yang bersifat lamban tapi pasti, melalui berbagai budaya yang telah dikenal masyarakat, namun menggunakan pesan lain, 
yakni Islam. (Rifa'I, 2008: 119-121) Setidaknya ada beberapa bukti pendekatan kultural dalam dakwah Walisongo, yaitu: Pertama, pendirian masjid dengan arsitektur Jawa (Hindu-Budha); Kedua, menghargai plot cerita Mahabrata yang ada namun disisipkan ke dalam unsur aqidah, ibadah, akhlak maupun tasawuf menurut ajaran Islam; Ketiga, memasukkan do'a Islam ke dalam adat-istiadat Hindu-Budha, seperti sesaji atau selamatan; Keempat, mencipta dan mengubah lagu atau tembang Jawa(Hindu-Budha) ke dalam bentuk Islami; Kelima, membuat gamelan sekaten; Keenam, menciptakan seni ukir; dan banyak bentuk dakwah lain yang mengakomodasi budaya setempat.

Fenomena tersebut merupakan proses dakwah kultural yang dilakukan dalam budaya yang berbeda. Perbedaan dalam dakwah kultural tidak mesti harus dihilangkan selama tidak bertentangan dengan nilai-nilai ajaran Islam. Menerima perbedaan merupakan suatu keniscayaan karena Islam ada shalih li kulli zaman wa al-makan.

\section{DIALEKTIKA AL-QUR'AN DENGAN REALITAS MASYARAKAT ARAB}

Berbicara proses dialektika al-Qur'an dengan realitas Arab berarti menelaah cara teks (al-Qur'an) berdialog dengan konteks. Namun perlu diketahui, yang dimaksud dengan konteks di sini bukan sekedar peristiwa yang melatarbelakangi munculnya satu teks, tetapi lebih tepatnya adalah social-bistoris masyarakat Arab sebagai tempat turunnya al-Qur'an. Dengan kata lain, al-Qur'an turun memberi respon terhadap kebudayaan tersebut dengan merekonstruksi dan dekonstruksi atau al-Qur'an memberikan solusi terhadap problem sosial yang muncul pada saat itu.(Sodiqin, 2008: 13)

Dalam hal ini, turunnya al-Qur'an mengindikasikan ada proses hubungan timbal balik (resiprokasi) antara wahyu dengan realitas. Artinya, terjadi dialogis antara ayat al-Qur'an dengan setting sosial-kultural masyarakat Arab sebagai tempat turunnya wahyu. Hal ini terlihat banyaknya adat istiadat Arab yang terekam dan berdialektis dengan alQur'an. Adat istiadat tersebut meliputi berbagai bidang, baik pranata keagamaan, sosial, ekonomi, politik, maupun hukum. Dalam beberapa ayatnya, al-Qur'an bersifat apresiatif terhadap budaya yang ada dengan menegaskan keberlakuannya dan memberikan ketentuan-ketentuan baru di dalamnya. Dalam hal ini, al-Qur'an menyempurnakan aturan-aturan yang sudah ada sehingga masyarakat arab dapat melanjutkan kebiasaan tersebut.

Berkenaan dengan masalah dialektika wahyu dengan realitas, Ali Sadikin mengelompokkan sikap al-Qur'an dalam merespon tradisi Arab 
kepada tiga bentuk, yaitu: tahmil (menerima dan melanjutkan tradisi), tahrim (melarang keberadaan tradisi), dan taghyir (menerima dan merekonstruksi tradisi).(Sodiqin, 2008: 116-117)

\section{Tabmil (adoptive-complement)}

Sikap ini ditunjukkan dengan adanya ayat-ayat yang menerima dan melanjutkan keberadaan tradisi serta menyempurnakan aturannya. Apresiasi tersebut tercermin dari ketentuan atau aturan yang bersifat umum serta tidak merubah paradigma keberlakuannya. Bersifat umum, artinya ayat-ayat yang mengatur tidak menyentuh masalah yang mendasar dan nuansanya berupa anjuran bukan perintah. Termasuk dalam kelompok ini adalah masalah perdagangan dan penghormatan bulan-bulan haram. Respon al-Qur'an terhadap kedua masalah ini telihat apresiatif dalam pesan-pesannya. Seperti membedakan praktek riba dengan jual beli, al-Quran menyebutkan jual beli adalah halal dan riba itu haram.

"Orang-orang yang Makan (mengambil) riba tidak dapat berdiri melainkan seperti berdirinya orang yang kemasukan syaitan lantaran (tekanan) penyakit gila. Keadaan mereka yang demikian itu, adalah disebabkan mereka berkata (berpendapat), Sesungguhnya jual beli itu sama dengan riba, Padahal Allah telah menghalalkan jual beli dan mengharamkan riba. orang-orang yang telah sampai kepadanya larangan dari Tuhannya, lalu terus berhenti (dari mengambil riba), Maka baginya apa yang telah diambilnya dahulu (sebelum datang larangan); dan urusannya (terserah) kepada Allah. orang yang kembali (mengambil riba), Maka orang itu adalah penghuni-penghuni neraka; mereka kekal di dalamnya. (Q.S. [2]: 275)

Perdagangan merupakan profesi yang dilakukan oleh bangsa Arab, bahkan menjadi bagian dari kehidupan mereka. Berbagai bentuk transaksi dipraktekkan oleh masyarakat, mulai dari pergadaian, utang piutang, salam, dan lain-lain. Namun dibalik itu, berbagai bentuk kedhaliman dan ketidakadilan dipraktekkan dalam berbagai transaksi tersebut. Seolah-olah hal tersebut merupakan bagian dari transaksitransaksi. Menanggapi dagang yang dipraktekkan, al-Qur'an tetap melegitimasi kebolehannya, namun membedakan antara jual beli dan kebathilan. Dengan kata lain, jual beli (dagang) dibolehkan, sedangkan kebathilan tidak, seperti riba dan gharar. Intinya, al-Qur'an melanjutkan praktek dagang sebagai bagian dari budaya Arab dalam sistem yang Qur'ani.

Begitu juga melarang melakukan peperangan di bulan haram (Dzulqaidah, Drulbijjah, dan Mubarram, Rajab) karena menghormati bulan tersebut. 
"Bulan Haram dengan bulan haram, dan pada sesuatu yang patut dihormati, Berlaku hukum qishaash. oleh sebab itu Barangsiapa yang menyerang kamu, Maka seranglah ia, seimbang dengan serangannya terhadapmu. bertakwalah kepada Allah dan ketahuilah, bahwa Allah beserta orang-orang yang bertakwa. (Q.S. [2]: 194)

(Musim) haji adalah beberapa bulan yang dimaklumi, Barangsiapa yang menetapkan niatnya dalam bulan itu akan mengerjakan haji, Maka tidak boleh rafats[123], berbuat Fasik dan berbantah-bantahan di dalam masa mengerjakan haji. dan apa yang kamu kerjakan berupa kebaikan, niscaya Allah mengetahuinya. Berbekallah, dan Sesungguhnya Sebaik-baik bekal adalah takwa dan bertakwalah kepada-Ku Hai orang-orang yang berakal. (Q.S. [2] 197)

"Mereka bertanya kepadamu tentang berperang pada bulan Haram. Katakanlah: "Berperang dalam bulan itu adalah dosa besar; tetapi menghalangi (manusia) dari jalan Allah, kafir kepada Allah, (menghalangi masuk) Masjidilharam dan mengusir penduduknya dari sekitarnya, lebih besar (dosanya) di sisi Allah. dan berbuat fitnah lebih besar (dosanya) daripada membunuh. mereka tidak henti-hentinya memerangi kamu sampai mereka (dapat) mengembalikan kamu dari agamamu (kepada kekafiran), seandainya mereka sanggup. Barangsiapa yang murtad di antara kamu dari agamanya, lalu Dia mati dalam kekafiran, Maka mereka Itulah yang sia-sia amalannya di dunia dan di akhirat, dan mereka Itulah penghuni neraka, mereka kekal di dalamnya. (Q.S. [2]: 217)"

Bagi masyarakat Arab Dzulqaidah, Dzulhijjah, dan Mubarram merupakan bulan yang hormati. Menurut Ali Sadiqin keempat bulan tersebut mempunyai arti penting bagi kehidupan sosial religius masyarakat Arab. Bulan Dzulqaidah, Dzulbijah, dan Mubarram dihormati pelaksanaan ibadah haji dilaksanakan pada bulan tersebut. Sedangkan bulan Rajab bagi masyarakat Arab merupakan bulan ganjil. Kebiasaan tersebut tetap dilanjutkan oleh al-Qur'an, bahkan segala bentuk larangan di masa masyarakat Arab pra-Islam tetap diakui sebagai bagian dari ajaran Islam. Lebih tegas lagi, al-Qur'an menganggap berdosa ketika larangan-larangan tersebut dikerjakan.

\section{Tabrim (detructive)}

Sikap ini ditunjukkan dengan melarang kebiasaan-kebiasaan masyarakat Arab yang disertai dengan ancaman bagi yang melakukannya. Pelarangan yang dilakukan secara bertahap dan manusiawi. Secara bertahap maksudnya, al-Qur'an tidak langsung menetapkan hukum 
larangan dalam satu waktu, namun mempunyai tahapan-tahapan. Secara manusiawi, artinya, berusaha mengajak manusia berdialog tentang keberadaan tradisi tersebut yang banyak mendatangkan kemudharatan. Jadi, al-Qur'an tidak serta merta melarang tanpa menjelaskan dampak negatifnya bagi masyarakat.(Sodiqin, 2008: 117)Termasuk dalam masalah ini adalah berjudi, minum khamr (QS. an-Nahl [16]: 67, al-Baqarah [2]: 2, an-Nisa' [4]: 43, dan al-Maidah [5]: 90-91), praktik riba (Q.S. ar-Rum [30]: 39, al-Baqarah [2]: 275-276, 278-279.), dan perbudakan (Mengenai dengan pelarangan perbudakan, dalam al-Qur'an diapresiasikan dalam bentuk persamaan derajat (Q.S. al-Hujarat [49]: 11), anjuran memerdekakan budak (Q.S. al-Baqarah [2]: 177), menikahi mereka lebih dari menikahi orang musyrik (Q.S. al-Baqarah [2]: 221).

Bermain judi dan minum khamar merupakan perbuatan yang sering dilakukan, bahkan menjadi tradisi yang mengakar dalam kehidupan masyarakat Arab. Mengalihkan dan menghilangkan kebiasaan tersebut sangatlah sulit karena sudah dianggap kebutuhan. Untuk merubah hal tersebut, al-Qur'an tidak mengharamkan secara total, namun membuka kesadaran masyarakat Arab akan bahaya ketika praktek tersebut diteruskan. Jika upaya tersebut sudah berhasil, al-Qur'an melakukan pengharaman dalam waktu tertentu saja. Ketika kesadaran sudah mantap pada diri mereka al-Qur'an baru melanjutkan keharaman secara total.

Begitu juga dalam kasus-kasus lain yang telah disebutkan di atas, pengharaman dilakukan secara bertahap (tadarruj). Misalnya, perbudakan pada awalnya tidak ada pengharaman secara total. Jika itu dilakukan maka akan terjadi berbagai ketidakadilan dalam ekonomi dan sosial masyarakat yang disebabkan oleh budak-budak yang belum mandiri dan belum siap dimerdekakan. Mengawali pelarangan tersebut, a-Qur'an menggambarkan akan arti pentingnya sebuah kebebasan hidup. Begitu juga persoalan perkawinan yang dipraktekkan tanpa batas, al-Qur'an membatasi dalam batas tertentu kemudian mengikat dengan "keadilan".

\section{Tagyir (adoptive-reconstructive)}

Tagyir merupakan sikap al-Qur'an yang menerima tradisi Arab dan melakukan rekonstruksi dengan memodifikasinya sehingga berubah karakter dasarnya.(Sodiqin, 2008: 130) Artinya, al-Qur'an mengakomodasi tradisi dan mengatur kembali dengan kerangka baru. Secara simbolik, tradisi tersebut tetap dipertahankan, tapi ketentuan-ketentuan yang berlaku diubah. Perubahan ini didasari oleh dampak nyata dari tradisi tersebut yang menimbulkan ketidakstabilan sosial dalam masyarakat serta kemorosotan moral. Banyak tradisi Arab yang mengakibatkan adanya dominasi atau perlakuan tidak adil terhadap kelompok atau suku tertentu. Namun keberadaan tradisi tersebut sudah menjadi bagian yang tak dapat 
dipisahkan dari sistem social masyarakat, sehingga al-Qur'an hanya mengonstruksinya dengan tetap mengakui keberadaanya.

Termasuk dalam kelompok ini adalah pakaian dan aurat wanita, lembaga perkawinan, anak angkat, hukum waris, dan qishash-diyat. Masalah pakaian, al-Qur'an merubah model pakaian wanita Arab yang sebelumnya dianggap kurang sopan, seperti pakaian panjang yang dipakai tapi kelihatan betisnya, dada terbuka tanpa ada kain penutup.(Sodiqin, 2008: 129)Al-Qur'an merekonstruksi model berpakaian wanita Arab dengan model yang ditawar al-Qur'an agar lebih sopan dan bermartabat.

"Katakanlah kepada wanita yang beriman: "Hendaklah mereka menahan pandangannya, dan kemaluannya, dan janganlah mereka Menampakkan perhiasannya, kecuali yang (biasa) nampak dari padanya. dan hendaklah mereka menutupkan kain kudung kedadanya, dan janganlah Menampakkan perhiasannya kecuali kepada suami mereka, atau ayah mereka, atau ayah suami mereka, atau puteraputera mereka, atau putera-putera suami mereka, atau saudara-saudara laki-laki mereka, atau putera-putera saudara lelaki mereka, atau putera-putera saudara perempuan mereka, atau wanita-wanita Islam, atau budak- budak yang mereka miliki, atau pelayan-pelayan laki-laki yang tidak mempunyai keinginan (terhadap wanita) atau anak-anak yang belum mengerti tentang aurat wanita. dan janganlah mereka memukulkan kakinya agar diketahui perhiasan yang mereka sembunyikan. dan bertaubatlah kamu sekalian kepada Allah, Hai orang-orang yang beriman supaya kamu beruntung. (an-Nur [24]:31)

“ Hai Nabi, Katakanlah kepada isteri-isterimu, anak-anak perempuanmu dan isteri-isteri orang mukmin: "Hendaklah mereka mengulurkan jilbab keseluruh tubuh mereka". yang demikian itu supaya mereka lebih mudah untuk dikenal, karena itu mereka tidak diganggu. dan Allah adalah Maha Pengampun lagi Maha Penyayang." (al-Ahzab [33]: 59)

Masalah lembaga perkawinan, al-Qur'an merubah kepada sistem yang lebih manusiawi karena dalam perkawinan masyarakat Arab pra Islam mahar diartikan sebagai alat transaksi yang diberikan kepada wali dan laki-laki diperbolehkan berpoligami tanpa batas. (Rahman, 1987: 59) Dalam hal ini, al-Qur'an merekonstruksi dengan sistem yang manusiawi, seperti merubah paradigma mahar menjadi hadiah perkawinan bagi perempuan.

"berikanlah maskawin (mahar) kepada wanita (yang kamu nikahi) sebagai pemberian dengan penuh kerelaan. kemudian jika mereka menyerahkan kepada kamu sebagian dari maskawin itu dengan 
senang hati, Maka makanlah (ambillah) pemberian itu (sebagai makanan) yang sedap lagi baik akibatnya. (Q.S. al-Nisa' [4]: 4)

Membatasi poligami maksimal empat orang.

" dan jika kamu takut tidak akan dapat Berlaku adil terhadap (hakhak) perempuan yang yatim (bilamana kamu mengawininya), Maka kawinilah wanita-wanita (lain) yang kamu senangi : dua, tiga atau empat. kemudian jika kamu takut tidak akan dapat Berlaku adil, Maka (kawinilah) seorang saja, atau budak-budak yang kamu miliki. yang demikian itu adalah lebih dekat kepada tidak berbuat aniaya. (Q.S. alNisa' [4]: 3)

Adapun masalah warisan, al-Qur'an merubah tradisi dengan memberikan hak kepada anak perempuan yang sebelumnya tidak ada.

"Allah mensyari'atkan bagimu tentang (pembagian pusaka untuk) anak-anakmu. Yaitu : bahagian seorang anak lelaki sama dengan bahagian dua orang anak perempuan dan jika anak itu semuanya perempuan lebih dari dua, Maka bagi mereka dua pertiga dari harta yang ditinggalkan; jika anak perempuan itu seorang saja, Maka ia memperoleh separo harta. dan untuk dua orang ibu-bapa, bagi masing-masingnya seperenam dari harta yang ditinggalkan, jika yang meninggal itu mempunyai anak; jika orang yang meninggal tidak mempunyai anak dan ia diwarisi oleh ibu-bapanya (saja), Maka ibunya mendapat sepertiga; jika yang meninggal itu mempunyai beberapa saudara, Maka ibunya mendapat seperenam. (Pembagian-pembagian tersebut di atas) sesudah dipenuhi wasiat yang ia buat atau (dan) sesudah dibayar hutangnya. (Tentang) orang tuamu dan anak-anakmu, kamu tidak mengetahui siapa di antara mereka yang lebih dekat (banyak) manfaatnya bagimu. ini adalah ketetapan dari Allah. Sesungguhnya Allah Maha mengetahui lagi Maha Bijaksana”. (Q.S alNisa' [4]: 11)

Masalah adopsi anak, al-Qur'an merubah bahwa anak angkat tidak bisa dijadikan anak kandung dan ia berbeda hak dengan anak kandung.

Allah sekali-kali tidak menjadikan bagi seseorang dua buah hati dalam rongganya; dan Dia tidak menjadikan istri-istrimu yang kamu zhihar[1198] itu sebagai ibumu, dan Dia tidak menjadikan anak-anak angkatmu sebagai anak kandungmu (sendiri). yang demikian itu hanyalah perkataanmu dimulutmu saja. dan Allah mengatakan yang sebenarnya dan Dia menunjukkan jalan (yang benar). (Q.S. al-Ahzab [33]: 4) 
Mengenai qishash-diyat, al-Qur'an melegetimasi hukum qishashdiyat dengan pembalasan yang seimbang.

Hai orang-orang yang beriman, diwajibkan atas kamu qishaash berkenaan dengan orang-orang yang dibunuh; orang merdeka dengan orang merdeka, hamba dengan hamba, dan wanita dengan wanita. Maka Barangsiapa yang mendapat suatu pema'afan dari saudaranya, hendaklah (yang mema'afkan) mengikuti dengan cara yang baik, dan hendaklah (yang diberi ma'af) membayar (diat) kepada yang memberi ma'af dengan cara yang baik (pula). yang demikian itu adalah suatu keringanan dari Tuhan kamu dan suatu rahmat. Barangsiapa yang melampaui batas sesudah itu, Maka baginya siksa yang sangat pedih. (Q.S. al-Baqarah [2]: 178)

Selain dari itu, dialektika al-Qur'an dengan realitas juga telihat dari ayat-ayat al-Qur'an yang diturunkan sesuai dengan watak kepribadian masyarakat di mana al-Qur'an diturunkan, seperti masyarakat Mekkah yang berprofesi sebagai pedagang yang mengakibatkan mereka berpikir serba material, terjadinya ketidakadilan, sulit menerima kebenaran, dan percaya pada takhayul. Al-Qur'an datang meluruskan keyakinan mereka dengan membawa ajaran tauhid, yaitu mentranformasikan ajaran tauhid ke dalam masyarakat disesuaikan dengan tingkat pemikiran mereka yang tujuannya untuk membebaskan mereka dari ketergantungan terhadap segala aspek, baik ekonomi, politik, social, maupun budaya. (Sodiqin, 2008: 90) Begitu juga dengan masyarakat Madinah yang heterogen, di mana terdapat banyak suku dan kelompok masyarakat yang saling bermusuhan. Al-Qur'an datang menekankan reformasi struktural, baik politik maupun sosial kemasyarakatan. (Soetapa, 1991: 69)

Selain itu, dari aspek bahasa juga terlihat al-Qur'an mengakomodasi sosio-linguistik masyarakat Arab ketika itu. Bahasa yang ditampilkan al-Qur'an mempunyai corak khusus yang tidak hanya mengacu pada dunia fisik semata, namun mengatasi ruang dan waktu, mengacu dimensi ilahiyah dan metafisika. Pola tersebut sebagai bentuk jawaban al-Qur'an terhadap kehidupan bangsa Arab di Padang pasir. Kerasnya situasi pada pasir membuat masyarakat Arab lebih tegas karena selalu menghadapi rasa putus asa dan ketakutan Namun dibalik itu, watak mereka juga memiliki jiwa seni yang halus dalam bidang sastra. (Muzakki, 2007:56) Menjawab realitas tersebut al-Qur'an tampil dan bahasa yang tegas, namun bernilai sastra yang tinggi. Menampilkan bahasa yang tegas lagi bersastra tinggi bertujuan untuk memberi pesan yang terkesan dalam alam kesadaran masyarakat Arab. Apalagi memahami indah dan tidaknya bahasa atau tinggi dan rendahnya nilai sastra masyarakat Arab merupakan ahlinya. 


\section{FORMAT KOMUNIKASI DALAM DAKWAH KULTURAL VERSI DIALEKTIKA AL-QUR'AN DENGAN REALITAS MASYARAKAT ARAB}

Melihat cara al-Qur'an berdialektika dengan budaya Arab ketika itu, memberi berbagai format pengetahuan dalam berkomunikasi dan berinteraksi dengan individu maupun kelompok dalam suatu komunitas. Hal ini berdasarkan asumsi bahwa pesan yang disampaikan individu pada individu lain atau kelompok pada kelompok lain tidaklah dalam ruang yang hampa, namun ada budaya dan tradisi yang melingkupi kehidupan suatu masyarakat. Bagi mereka budaya dan tradisi tersebut sudah menjadi bagian dari kehidupan yang mesti dilakukan dalam berbagai aktivitas social. Merubah hal tersebut tidak mungkin dilakukan seperti membalik telapak tangan, melainkan perlu adanya pola yang jitu agar pesan yang disampaikan dapat diterima dan membentuk kesadaran sesuai dengan tujuan pesan.

Untuk dapat melakukan hal tersebut, al-Qur'an (sebagaimana dijelaskan sebelumnya) telah memberikan pola tersebut dari proses turun dalam komunitas Arab ketika itu. Al-Qur'an tidak langsung memaksa masyarakat Arab untuk mengikuti apa yang diinginkan al-Qur'an. Hal ini bukan berarti ketidakmampuan al-Qur'an untuk merubah suatu tradisi, namun al-Qur'an bermaksud menumbuhkan kesadaran pada masyarakat tersebut akan kekeliruan yang selama ini mereka kerjakan. Dengan demikian, penerimaan mereka terhadap ajaran yang disampaikan melalui al-Qur'an bukanlah keterpaksaan, melainkan kesadaran yang tumbuh dari sebuah kesalahan. Mungkin lebih tepatnya dapat dikatakan mengajak bukan menghakimi.

Terkait dengan dakwah kultural, penggunaan model dialektika alQur'an dengan realitas sebagai pola melaksanakan aktivitas dakwah kultural merupakan hal yang sangat relevan. Karena menggunakan suatu budaya tidak mesti harus dilarang total, namun ada aspek-aspek yang dapat digunakan untuk dilanjutkan atau hanya dirubah . Dengan demikian, individu atau komunitas sebagai sasaran penyampaian pesan merasa lebih dihargai.

Pelarangan (tahrim) dapat dilakukan terhadap suatu budaya, jika kondisi budaya tersebut bertentangan dengan ajaran-ajaran Islam., namun tetap harus diperhatikan aspek-aspek psikologis, ekonomi, dan sosial. Ketiga hal tersebut biasanya menjadi pemicu masyarakat mempertahankan suatu tradisi. Belajar dari proses pengharaman perbudakan, al-Qur'an tetap memperhatikan dampak ekonomi jika memerdekakan semua budak dalam satu masa. Oleh sebab itu, memerdekakan budak tetap diperhatikan aspek 
kemandirian dengan ketentuan mampu membeli dirinya (mukhatab). Begitu juga pengharam minuman keras, secara psikologi masyarakat Arab beranggapan minuman tersebut memberi ketenangan dan kenyaman bagi mereka. Dalam hal ini, al-Qur'an melarang kebiasaan tersebut tidak langsung, melainkan secara bertahap.

Jika tidak bertentangan, tidak perlu dilakukan pelarangan, melainkan cukup dengan perubahan (tagyir) atau mempertahankan (tahmit) tradisi tersebut. Melakukan perubahan yang dimaksudkan adalah merubah bagian-bagian tertentu yang dianggap tidak sesuai, namun tetap mempertahankan eksistensi tradisi tersebut. Sedangkan mempertahankan merupakan melanjutkan tradisi-tradisi tersebut sebagaimana utuhnya.

Pola tersebut dapat menjadi panduan dalam dakwah kultural. Menghadapi masyarakat dengan coraknya sendiri tidak harus menampakkan sikap konfrontasi, meskipun tradisi yang mereka praktekkan bertentangan dengan syariat Islam. Da'i dituntut harus menahan diri dan lebih menampilkan pendekatan yang persuasif. Jika sikap konfrontasi yang ditampilkan maka penerimaan terhadap suatu pesan didasari oleh keterpaksaan bukan kesadaran yang muncul dalam diri individu atau kelompok sasaran dakwah. Pola tersebut bukan mustahil suatu saat mereka akan melakukan konversi atau resistensi terhadap ajaran-ajaran yang disampaikan. Maka oleh sebab langkah awal yang perlu dilakukan da'i adalah menumbuhkan kesadaran terhadap objek bahwa tradisi yang dipertahankan bertentangan dengan ajaran-ajaran agama.

Selain itu, bahasa yang digunakan da'i juga harus mencerminkan tempat di mana dakwah disampaikan. Pemilihan bahasa dianggap penting karena efektivitas komunikasi dan tranformasi dari pemberi pesan kepada penerima pesan adalah dari penggunaan bahasa yang mudah dipahami dan familiar dengan kondisi sosio-linguistik penerima pesan. Dengan demikian, penerima pesan akan mudah menangkap dan memahami isi pesan karena disampaikan dengan bahasa yang mudah dipahami. Sebagaimana bahasa dalam a-Qur'an tidak hanya sebagai penyampai pesan, namun digunakan untuk membangkitkan kesadaran dalam beragama. (Zaid: 2005:3)

Penggunaan pola dialektika al-Qur'an dengan realitas sebagai acuan dakwah kultural akan melahirkan Islam yang bervariasi dan unik dengan nuansa local. Variasi tersebut bukan berarti Islam sudah tercabut dari sumbernya melainkan ada proses akulturasi Islam yang disampaikan mad'un dengan budaya local. Dengan kata lain, terjadi suatu proses internalisasi ajaran Islam sebagai pesan yang disampaikan mad'un dalam konteks budaya local. Paisun mengistilahkan proses inkulturasi yang melahirkan karakteristk local atau islam kultural. (Paisun, 2010: 156) 


\section{KESIMPULAN}

Dakwah kultural merupakan upaya untuk memahami dan menggunakan potensi-potensi kultural masyarakat Islam sebagai wahana untuk menanamkan Islam yang membumi, yakni Islam yang bisa merubah potensi menjadi gerak kemajuan social. Untuk menggunakan dakwah kultural dalam aktivitas dakwah, proses dialektika al-Qur'an dengan realitas dapat menjadi sebuah acuan pelaksanaan. Ada tiga cara dialektika al-Qur'an yang dapat dijadikan, yaitu: taghyir, tabrim, dan tabmil. 


\section{DAFTAR PUSTAKA}

Ali, Abdullah. 2007. Sosiologi Pendidikan dan Dakwah, Yogyakarta: Cakrawala

al-Qazwini, Al-Khatib. T.th, al-Idhabu fi Ulumu al-Balaghah; al-Ma'ani, alBayan, al-, Badi', Beirut: Dar al-Kutûb al-Ilmiyyah

Ismail, A. Ilyas. 2006,Paradigma Dakwah Sayyid Quthub; Rekonstruksi Pemikiran Dakwah Harakah, Jakarta: Penamadani

Koentjaningrat. 1976. Kebudayaan, Mentaliltet dan Pembangunan, (Jakarta: Gramedia

M. Syaifuddin, Zuhriy. 2011. Budaya Pesantren dan Pendiidkan Karakter pada Pondok Pesantren Salaf, Jurnal Walisongo, Vol. 19 Nomor 2 November 2011

Muzakki, Ahmad.2007.Dialektika Gaya Bahasa al-Qur'an dan Budaya Arab Pra-Islam; Sebuah Kajian Sosiologi Bahasa, Jurnal Islamica, Vol. 2, No. 1

Paisun. 2010, Dinamika Islam Kultural: Studi atas Dialektika Islam dan Budaya Lokal,Madura, el-Harakah, Vol. 12, No.2, Tahun 2010

Pusat Dakwah Indonesia. 2002, Forum Dakwah Jakarta, Jakarta: t.tp

Rahman ,Fazlur, 1987. Islam, terj. Senoaji Saleh,Jakarta: Bina Aksara, 1987

Rifa'i, Afif. 2008. Pendekatan Kultural dalam Dakwah "Walisongo", Artikel Perpustakaan UIN Sunan Kalijaga Yogyakarta

Sodiqin, Ali. 2008. Antropologi al-Qur'an; Model Dialektika Wabyu dan Realitas, Yogyakarta: ar-Ruzz Media

Soetapa, Djaka. 1991. Ummah Komunitas Religius, Sosial dan Politik dalam alQur'an, Yogyakarta: Duta Wacana University Press

Subaidi. 2014. Politik Kultural KH. Abdurrabman Wabid dalam Demokratisasi, Asy-Syir'ah, Jurnal Ilmu Syari'ah dan Hukum, Vol. 48, No. 1, Juni 2014 
Sulthon. 2003. Menjawab Tantangan Zaman Desain Ilmu Dakwah Kajian

Ontologis, Epistemologis, dan Aksiologis, Cet. I: Yogyakarta: Pustaka Peiajar

Sunarto. 2013, A., Kyai dan Prostitusi: Pendekatan Dakwah KH. Mubammad Khoiron Suaeb di Lokalisasi Kota Surabaya, Jurnal Komunikasi Islam, volume 03, Nomor 02

Suparto. 2009. Dakwah Kultural Muhammadiyah antara Pembaharuan dan Pembauran, Jurnal al-Haraqah, Vol. II, No. 2, 2009

Zaid, Nasr Hamid Abu. 2005.Tekstualitas al-Qur'an: Kritik terhadap Ulumul Qur'an, Yokyakarta: LKiS 